\title{
Diagnosis of the nutritional status of 'Paluma' guava trees using leaf and flower analysis
}

\author{
Cibelle Tamiris de Oliveira ${ }^{1}$, Danilo Eduardo Rozane ${ }^{2}$ Daniel Angelucci de Amorim³ \\ Henrique Antunes de Souza ${ }^{4}$, Beatrice Santana Fernandes ${ }^{5}$, William Natale ${ }^{6}$
}

\begin{abstract}
The present study aimed to compare the use of leaf and flower analysis and to verify the most appropriate organ for the diagnosis of the nutritional status of guava trees. The evaluation was carried out using the CND (Compositional Nutrient Diagnosis) methodology, using yield and nutritional contents of the leaf and flower of 'Paluma' guava trees in 48 plots of an irrigated orchard. The contents of flower and leaf nutrients were submitted to variance analysis, by the Tukey test at $5 \%$, and the nutrient sufficiency ranges in organs were calculated, as well as the correlations between multi-nutrient variables and yield. Significant differences between contents of nutrients in flower and leaf, as well as greater variability in the nutritional contents in leaf, were observed. The sufficiency ranges of flower proved to be shorter compared to leaf. The number of correlations between nutrients and yield was higher in the flower. The greater sensitivity of the leaf analysis in expressing interactions between nutrients and yield indicates that this organ can also be used for the nutritional diagnosis of guava trees.
\end{abstract}

Index terms: Psidium guajava; nutritional status assessment; tissue analysis; CND.

\section{Diagnóstico do estado nutricional de goiabeiras 'Paluma' utilizando análise de folha e flor}

Corresponding author: cibelleolv@gmail.com

Received: August 27, 2019 Accepted: March 09, 2020

Copyright: All the contents of this journal, except where otherwise noted, is licensed under a Creative Commons Attribution License.

$((c)) \mathrm{E}$

\begin{abstract}
Resumo - O presente trabalho teve como objetivo comparar a utilização da análise de folha e flor, e verificar o órgão mais adequado para o diagnóstico do estado nutricional de goiabeiras. A avaliação foi realizada por meio da metodologia $C N D$ (Diagnose da Composição Nutricional), utilizando rendimento e teores nutricionais de flor e folha de goiabeiras 'Paluma', em 48 parcelas de um pomar irrigado. Os teores dos nutrientes de flor e folha foram submetidos à análise de variância, pelo teste de Tukey, a 5\%, e calcularam-se as faixas de suficiência dos nutrientes nos órgãos, bem como as correlações entre as variáveis multinutrientes e o rendimento. Observou-se diferença significativa entre os teores de nutrientes na flor e na folha, bem como maior variabilidade dos teores nutricionais na folha. Os intervalos das faixas de suficiência da flor mostraram-se menores em comparação com a folha. O número de correlações entre os nutrientes e o rendimento foi maior na flor. A maior sensibilidade da análise floral, em expressar as interações entre os nutrientes e a produtividade, indica que esse órgão também pode ser utilizado para o diagnóstico nutricional de goiabeiras.
\end{abstract}

Termos para indexação: Psidium guajava; avaliação do estado nutricional; análise de tecido; $C N D$.

\footnotetext{
${ }^{1}$ Master in Soil Sciences, PhD student, Graduate Program in Soil Sciences, Federal University of Paraná (UFPR), Curitiba-PR, Brazil. Capes fellow. Email: cibelleolv@gmail.com (ORCID 0000-0002-2957-0969)

${ }^{2}$ Associate Professor, “Júlio de Mesquita Filho” State University of São Paulo, Registro-SP, Brazil. CNPq fellow. Email: danilo.rozane@unesp.br (ORCID 0000-0003-0518-3689)

${ }^{3}$ Researcher, Agricultural Research Company of Minas Gerais (EPAMIG), Uberaba-MG, Brazil. FAPEMIG fellow. email: daniel@epamig.br (ORCID 0000-0003-4921-5080)

${ }^{4}$ Researcher, Brazilian Agricultural Research Corporation (Embrapa Meio-Norte), Teresina-PI, Brazil. CNPq fellow. Email: henrique.souza@ embrapa.br (ORCID 0000-0002-2209-4285)

${ }^{5}$ Agronomist, Master student, Federal University of Santa Maria (UFSM), Santa Maria-RS, Brazil. Email: bia.santana996@gmail.com(0Rcid 0000-0002-3784-8860)

${ }^{6}$ Visiting Professor, Federal University of Ceará (UFC), Fortaleza-CE, Brazil. CNPq fellow, Email: natale@ufc.br (ORCID 0000-0001-9572-4463)
} 


\section{Introduction}

Guava (Psidium guajava) is one of the most important fruits in the world, occupying the $6^{\text {th }}$ position among the most produced fruits, along with mango and mangosteen (FAO, 2019). In Brazil, fruit production corresponds to, approximately, 288 thousand tons (IBGE, 2019).

For the plant to achieve good fruit production and quality it is necessary that, among other factors, the plant should be adequately supplied with the nutrients it needs. Although soil analysis is considered an established tool in agriculture (ROZANE et al., 2011), this technique is only effective for correcting soil fertility (TONIN et al., 2009), and does not necessarily match what the plant should acquire due to the interference of biotic and abiotic factors involved in nutrient absorption (NATALE; ROZANE, 2018).

Thus, the chemical plant tissue analysis appears as a complement to chemical soil analysis to adjust the supply of nutrients to the plant, because no one better than the plant itself to reflect what is being absorbed (MALAVOLTA et al., 1997). In the plant tissue analysis, the main organ used is the leaf, for it is the place where the greatest production of photosynthesis occurs and where the largest amount of nutrients absorbed by plants is located (LANA et al., 2010).

The works that carry out the nutritional diagnosis of plants use, for the most part, leaf analysis for this purpose. However, some studies that have used the flower to assess the nutritional status of avocado - Persea americana (RAZETO; SALGADO, 2004), coffee - Coffea sp. (MARTINEZ et al., 2003), citrus - Citrus sinensis L. Osbeck (PESTANA et al., 2001), apple - Malus domestica (SANZ et al., 1998), pear - Pyrus L. (SANZ et al., 1994 ), peach - Prunus persica (SANZ; MONTAÑÉS MÍLLAN, 1995) and olive - Olea europaea (KHELIL et al., 2010). The advantage of using flower analysis to assess nutritional status is that flowers are short-lived organs, in which there are no metabolic reactions as complex as in leaves, with no substantial differences between the total nutrient content and the physiologically active fraction (MONTAÑÉS MILLÁN et al., 1997; SANZ; MACHÍN, 1999). Moreover, it allows adjusting the fertilization program at the beginning of the fruit growing season, before irreversible losses in yield and quality occur (MARTINEZ et al., 2003).

CND (Compositional Nutrient Diagnosis) is among the methods used to interpret the leaf nutrient content. This methodology proposed by Parent and Dafir (1992) is based on the relationship between the content of a given nutrient and the geometric mean of the contents of other components in the dry matter, thus using multivariate relationships. There are frequent works in the literature using this methodology for leaf analysis (SERRA et al., 2010; CAMACHO et al., 2012; POLITI et al., 2013).

Thus, the present study aimed to assess whether flower analysis can be considered an alternative to leaf analysis in the diagnosis of the nutritional status of 'Paluma' guava trees using the CND methodology.

\section{Material and methods}

The study was carried out based on yield information and chemical leaf and flower analysis in a mineral fertilization test in a seven-year-old commercial 'Paluma' guava orchard spaced 7 x 5 meters, under irrigation system by micro-sprinkler. The orchard is located in the largest guava producing region in the state of São Paulo, municipality of Vista Alegre do Alto, with geographical coordinates $21^{\circ} 08 \mathrm{~S}$ and $48^{\circ} 30^{\prime} \mathrm{W}$ and altitude of 603 $\mathrm{m}$ a.s.l. According to the Köppen classification system, the climate is subtropical Cwa type with short, moderate and dry winter, hot and rainy summer, characterizing two distinct climatic seasons (ALVARES et al., 2013).

The soil of the area, classified as dystrophic REDYELLOW ARGISOL (EMBRAPA, 2006), was sampled in the projection of the plant canopy (at $1.75 \mathrm{~m}$ from the trunk) and between rows at the $0-0.40 \mathrm{~m}$ depth layer to characterize the initial chemical soil properties (Table 1).

Table 1. Chemical soil properties at the $0.0-0.40 \mathrm{~m}$ depth layer, in the fertilized row and between rows, before the installation of the experiment.

\begin{tabular}{|c|c|c|c|c|c|c|c|c|}
\hline & \multirow[t]{2}{*}{$\mathrm{pH}\left(\mathrm{CaCl}_{2}\right)$} & \multirow{2}{*}{$\begin{array}{c}\text { M.O } \\
\text { g dm}^{-3}\end{array}$} & \multirow{2}{*}{$\begin{array}{l}P(\text { resin) } \\
\mathrm{mg} \mathrm{dm}^{-3}\end{array}$} & $\mathrm{~K}$ & $\mathrm{Ca}$ & $\mathrm{Mg}$ & $\mathrm{H}+\mathrm{Al}$ & SB \\
\hline & & & & \multicolumn{5}{|c|}{------------------ $\mathrm{mmol}_{\mathrm{c}} \mathrm{dm}^{-3}$----------------- } \\
\hline Row & 5.6 & 10 & 13 & 2.1 & 25 & 11 & 14 & 39.1 \\
\hline \multirow[t]{3}{*}{ Between rows } & 5.8 & 10 & 10 & 2.8 & 26 & 12 & 12 & 41.3 \\
\hline & $\mathrm{T}$ & $\mathrm{V}$ & $\mathrm{B}$ & $\mathrm{Cu}$ & $\mathrm{Fe}$ & $\mathrm{Mn}$ & $\mathrm{Zn}$ & $\mathrm{S}^{2} \mathrm{SO}_{4}^{-2}$ \\
\hline & $\mathrm{mmol}_{\mathrm{c}} \mathrm{dm}^{-3}$ & $\%$ & \multicolumn{6}{|c|}{$--\mathrm{mg} \mathrm{dm}^{-3}$} \\
\hline Row & 53.1 & 73 & 0.16 & 8.1 & 12 & 11.5 & 0.3 & 2 \\
\hline Between rows & 53.3 & 77 & 0.25 & 9.3 & 11 & 11.6 & 0.3 & 3 \\
\hline
\end{tabular}


The experimental design used was randomized blocks with a $4 \times 4$ factorial scheme, with four nitrogen doses $\left(0 ; 0.5 ; 1\right.$ and $2 \mathrm{~kg}$ of $\left.\mathrm{N} \mathrm{plant}^{-1}\right)$ and four potassium doses $\left(0 ; 0.55 ; 1.1\right.$ and $2.2 \mathrm{~kg}$ of $\mathrm{K}_{2} \mathrm{O}$ plant $\left.^{-1}\right)$, and three replicates. The experimental plots consisted of five plants, considering the three central plants for evaluations. The experiment was conducted for three consecutive production cycles (February 2009 to April 2011). During the third production cycle considered in this research, the harvest period was between March and April 2011, with a database consisting of 48 plots.

The soil in the area was corrected ninety days before the installation of the experiment, and liming was performed as recommended by Natale et al. (1996). The sources of nutrients were urea $(45 \% \mathrm{~N})$, granulated potassium chloride $\left(60 \% \mathrm{~K}_{2} \mathrm{O}\right)$, simple superphosphate, zinc sulfate, and boric acid. $\mathrm{N}$ and $\mathrm{K}$ doses were split three times in the first cycle, every 30 days, and four times in the other cycles, every 25 days, starting in the pre-flowering phase. Phosphorus fertilization were stipulated according to recommendations of Natale et al. (1996), applied only once at each production cycle, together with the first $\mathrm{N}$ and $\mathrm{K}$ application. Zinc and boron fertilization were carried out via soil, together with herbicide application.

The orchard was irrigated with micro-sprinkler (ballerina type) by guava tree, keeping the soil moisture at $60 \%$ of the field capacity monitored by tensiometry at the 0.0 - $0.2 \mathrm{~m}$ layer. More information about the management carried out in the orchard, such as irrigation, pruning and pest, disease and weed control can be obtained from the works by Amorim et al. (2015a) and Amorim et al. (2015b).

In each plot, 12 freshly ripe pairs of leaves with petiole were collected, positioned as the third pair from the end of the branch, in the period of full crop flowering, at the median height of the guava tree (NATALE et al., 2007). In the same period, the same amount of flower was collected from branch and position in the plant. Leaf and flower samples were washed and dried in an oven with air circulation at $65^{\circ}-70^{\circ} \mathrm{C}$, until constant mass and then, they were ground for chemical determinations of nutrient contents $(\mathrm{N}, \mathrm{P}, \mathrm{K}, \mathrm{Ca}, \mathrm{Mg}, \mathrm{S}, \mathrm{B}, \mathrm{Cu}, \mathrm{Fe}, \mathrm{Mn}$, and $\mathrm{Zn}$ ), according to methodology indicated by Bataglia et al. (1983).

For production evaluation, all fruits from the three useful plants of each plot were collected and weighed during the period of plant fruiting at a stage suitable for industrialization, which corresponds to the phenological stage of fruit ripening (K:89), according to Salazar et al. (2006).

With yield data $\left(\mathrm{t} \mathrm{ha}^{-1}\right)$ and leaf and flower nutrient contents $\left(\mathrm{mg} \mathrm{kg}^{-1}\right)$, yields were classified in descending order, and calculations of CND indexes for flower and leaf were performed separately.
First, R was calculated (Equation 1), which represents a filling value, which added to the proportions of nutrients, which will correspond to $100 \%$ of the organ's dry matter.

$$
R=1000000-\sum_{i=1}^{n} N t_{i}
$$

where: $R$ represents all components not determined in the dry matter, in $\mathrm{mg} \mathrm{kg}^{-1} ; 1000000$ represents the total dry matter amount, in $\mathrm{mg} \mathrm{kg}^{-1} ; \mathrm{Nt}_{\mathrm{i}}$ is the content of each nutrient in the dry matter, in $\mathrm{mg} \mathrm{kg}^{-1}$.

The geometric mean (Equation 2) includes the contents of all nutrients plus the R-value, thus ensuring that all nutrients are accounted in the analysis of one sample, relating each component to all the others in the sample (PARENT; DAFIR, 1992).

$$
G=\left[\left(\prod_{i=1}^{n} N t_{i}\right) \cdot R\right]^{\frac{1}{(n+1)}}
$$

where: $G$ is the geometric mean of nutrient contents in the dry matter; $N t_{i}$ is the content of each nutrient in the dry matter; $R$ is the value of components not determined in the dry matter; $n$ is the number of nutrients analyzed.

Multi-nutrient variables (Equation 3) were calculated using the Neperian logarithm, which allowed generating better data distribution (BEVERLY, 1987).

$$
V_{i}=\ln \left(\frac{N t_{i}}{G}\right)
$$

where: $V i$ is the value of multi-nutrient variables; $G$ is the geometric mean of nutritional contents; $N t i$ is the content of each nutrient in the dry matter.

With the calculation of the Mahalanobis Distance (Equation 4), it was possible to identify and exclude outliers from the database.

$$
D^{2}=\left(c l r_{i}-\overline{c l} r_{l}\right)^{T} \operatorname{COV}^{-1}\left(c l r_{i}-\overline{c l r_{l}}\right)
$$

where: $D^{2}$ is Mahalanobis Distance; $c l r_{\mathrm{i}}$ is the sample to be compared; is the arithmetic mean of the reference population; $\mathrm{COV}$ is the covariance matrix of the reference population.

Based on $D^{2}$, the $\chi^{2}$ test was performed to exclude plots whose value was less than $1 \%$ probability $(\mathrm{p}<0.01)$.

Subsequently, the database was divided into the population of high (reference population) and low yield, based on the inflection point of the cubic function, adjusted among values of the accumulated function and $D^{2}$.

CND indexes for multi-nutrient variables were calculated according to Equation 5: 


$$
I_{i}=\frac{\left(V_{I}-\bar{V}_{l}\right)}{\sigma_{i}}
$$

where: $I i$ is the balance index of nutrient $i$ to determine $C N D ; V i$ is the value of the multi-nutrient variable $i$ of evaluated samples; $V_{\mathrm{i}}$ is the average of values of the multinutrient variable $i$ in the reference population; $\sigma_{i}$ is the standard deviation of variable $i$ in the reference population.

After obtaining the $C N D$ indexes for flower and leaf, discriminant analysis was performed with the aid of the R software. To obtain a more parsimonious model, that is, trying to establish a classification model using the most important variables (nutrients and yield), the discriminant analysis was carried out using the Forward Stepwise method. The Wilks Lambda test was also performed, which identified whether there was the difference between plant organs, in addition to the discriminant function, which indicated significantly important nutrients and the analysis of the correlation between nutrients and yield of the entire group, for flower and leaf. Statistical analyses were performed as indicated by Hair et al. (2005).

The determination of the sufficiency ranges for the contents of each nutrient in organs, similar to that carried out by Souza et al. (2015), was designed based on their respective nutritional balance indexes obtained by CND. The leaf contents of each nutrient were evaluated utilizing regression analysis, relating the nutrient contents with their respective CND indexes and adjusting the equation to the points. The lower limit (LL) and upper limit (UL) of the normal range were determined by equalizing the statistical models to zero to obtain the critical level (CL), subtracting and adding, respectively, the value found in the $2 / 3$ proportion of the standard deviation value for the contents of each nutrient.
The sufficiency ranges obtained in this study for leaf and flower were compared with those available in literature only for leaf (RAIJ et al., 1997; RIBEIRO et al., 1999; NATALE et al., 2002; PAULETTI; MOTTA, 2017), considered suitable for guava.

\section{Results and discussion}

'Paluma' guava database, composed of 48 experimental plots, showed yield between 20.5 and $73.8 \mathrm{t}$ $\mathrm{ha}^{-1}$, with a standard deviation of $13.8 \mathrm{tha}^{-1}$. The use of the Mahalanobis distance allowed excluding four outliers from the flower database and none for the leaf. Subsequently, the normal distribution of yield and multivariate relationships of nutrients in flower $(n=44)$ and leaf $(n=48)$ samples were performed. It was observed that all variables showed normal distribution by the Kolmogorov-Smirnov test, with $\mathrm{p}$ values greater than 0.05 .

The division of the sampled population by using the Mahalanobis distance allowed obtaining subpopulations of high and low yield, obtaining for flower average inflection point with the yield of $63.7 \mathrm{t} \mathrm{ha}^{-1}$, which was used as a base value for the division of high $\left(>63.7 \mathrm{t} \mathrm{ha}^{-1}\right)$ and low $\left(<63.7 \mathrm{t} \mathrm{ha}^{-1}\right)$ subpopulations. However, for leaf, the inflection point obtained was for the yield of $57.7 \mathrm{t} \mathrm{ha}^{-1}$. Yield above these points indicates high-yield plots and below indicate low-yield plots, pointing out that the flower was more restrictive to obtain the high-yield population, which is used to obtain CND indexes.

The contents of nutrients between flowers and leaves (Table 2) differed by the Tukey test at 5\% probability. It was observed that the average $\mathrm{P}, \mathrm{K}, \mathrm{Ca}$, $\mathrm{Mg}, \mathrm{B}$, and $\mathrm{Zn}$ contents were higher in flower than in leaf, with less variability in the nutrient contents of the flower, except for $\mathrm{Mg}, \mathrm{Fe}$, and $\mathrm{Mn}$. These results corroborate those obtained by Martinez et al. (2003) in coffee and Khelil et al. (2010) in olive trees.

Table 2. Sufficiency ranges, average contents and coefficients of variation (CV) of N, P, K, Ca, Mg, S, B, Cu, Fe, Mn, and $\mathrm{Zn}$ nutrients in 'Paluma' guava flowers and leaves.

\begin{tabular}{|c|c|c|c|c|c|c|}
\hline \multirow{2}{*}{ Nutrient } & \multicolumn{2}{|c|}{ Sufficiency ranges } & \multicolumn{2}{|c|}{ Average contents } & \multicolumn{2}{|c|}{$\mathrm{CV}$} \\
\hline & Flower & Leaf & Flower & Leaf & Flower & Leaf \\
\hline & & $\mathrm{g} \mathrm{kg}^{-1}$ & & & --------- & \\
\hline $\mathrm{N}$ & $14.3-15.7$ & $17.9-21.2$ & $14.9 \mathrm{~b}$ & $19.61 \mathrm{a}$ & 6.9 & 12.8 \\
\hline $\mathrm{P}$ & $1.6-1.8$ & $1.0-1.3$ & $1.72 \mathrm{a}$ & $1.27 \mathrm{~b}$ & 9.3 & 18.5 \\
\hline $\mathrm{K}$ & $18.2-19.4$ & $13.3-15.0$ & $18.46 \mathrm{a}$ & $14.21 \mathrm{~b}$ & 4.9 & 8.8 \\
\hline $\mathrm{Ca}$ & $6.4-7.5$ & $6.1-7.6$ & $7.01 \mathrm{a}$ & $6.4 b$ & 11.4 & 16.6 \\
\hline $\mathrm{Mg}$ & $1.8-2.2$ & $1.9-2.1$ & $2.12 \mathrm{a}$ & $1.98 \mathrm{~b}$ & 13.4 & 9.3 \\
\hline $\mathrm{S}$ & $1.8-2.0$ & $1.9-2.4$ & $1.86 \mathrm{~b}$ & $2.17 \mathrm{a}$ & 8.8 & 17.1 \\
\hline B & $173-208$ & $-131-190$ & $2087 a$ & $1704 \mathrm{~b}$ & 128 & ----- \\
\hline $\mathrm{Cu}$ & $26.6-32.4$ & $43.9-55.8$ & $27.6 \mathrm{~b}$ & $48.62 \mathrm{a}$ & 15.4 & 18.4 \\
\hline $\mathrm{Fe}$ & $19.7-49.3$ & $76.2-105$ & $44.92 b$ & $84.06 \mathrm{a}$ & 34.7 & 25.8 \\
\hline $\mathrm{Mn}$ & $41.5-72.9$ & $63.7-113.7$ & $53.81 \mathrm{~b}$ & $88.25 \mathrm{a}$ & 43.0 & 42.5 \\
\hline $\mathrm{Zn}$ & $19.6-23.2$ & $15.3-20.4$ & $22.2 \mathrm{a}$ & $17.1 \mathrm{~b}$ & 12.6 & 22.4 \\
\hline
\end{tabular}

Average contents followed by the same letter in the row do not differ by the Tukey's test at $\mathrm{p}<0.05$. 
Although the average contents of nutrients in the different organs are close, with significant differences between them, $\mathrm{Cu}, \mathrm{Fe}$ and $\mathrm{Mn}$ values in leaf stand out for exhibiting little less than double the value exhibited by the flower. These nutrients act mainly on leaves playing roles related to photosynthesis, respiration, enzyme activation, among others (YRUELA, 2005; MALAVOLTA, 2006; ALEXANDRE et al., 2012; MARSCHNER, 2012).
The correlation matrix (Table 3) between multinutrient variables and yield $(\mathrm{Y})$ of the total population for the organs under study showed, in general, the greater number of significant correlations for flower in comparison with leaf. Significant correlations only between multinutrient variables and $\mathrm{Y}$, also exhibited higher number in the flower, with $\mathrm{K}$ and $\mathrm{Mg}$ showing correlation only for this organ, and it could be inferred that flower shows greater sensitivity in expressing the interaction between nutrients and yield. Martinez et al. (2003), also observed the greater number of significant correlations in coffee flowers concerning leaves.

Table 3. Pearson's correlation matrix between multi-nutrient variables and yield $(\mathrm{Y})$ in the total leaf $(\mathrm{n}=48)$ and flower $(n=44)$ population of 'Paluma' guava trees.

\begin{tabular}{|c|c|c|c|c|c|c|c|c|c|c|c|c|}
\hline & $\mathrm{N}$ & $\mathrm{P}$ & K & $\mathrm{Ca}$ & $\mathrm{Mg}$ & $\mathrm{S}$ & B & $\mathrm{Cu}$ & $\mathrm{Fe}$ & $\mathrm{Mn}$ & $\mathrm{Zn}$ & $\mathrm{R}$ \\
\hline \multicolumn{13}{|c|}{ Leaf } \\
\hline $\mathrm{Y}$ & $0.40^{*}$ & $-0.66^{*}$ & -0.17 & $0.55^{*}$ & 0.01 & -0.28 & $-0.36^{*}$ & -0.05 & 0.04 & $0.49^{*}$ & 0.08 & $-0.58 *$ \\
\hline $\mathrm{N}$ & & $-0.59 *$ & -0.06 & 0.20 & 0.12 & -0.21 & $-0.71 *$ & 0.06 & -0.16 & $0.58 *$ & $-0.31^{*}$ & 0.04 \\
\hline $\mathrm{P}$ & & & 0.24 & $-0.40 *$ & 0.12 & $0.34 *$ & $0.64 *$ & -0.11 & -0.21 & $-0.70^{*}$ & 0.06 & $0.39 *$ \\
\hline $\mathrm{K}$ & & & & -0.13 & -0.21 & 0.26 & 0.19 & -0.13 & $-0.29 *$ & -0.20 & -0.09 & $0.33^{*}$ \\
\hline $\mathrm{Ca}$ & & & & & 0.25 & -0.02 & -0.02 & $-0.33 *$ & -0.15 & 0.17 & 0.10 & $-0.53 *$ \\
\hline $\mathrm{Mg}$ & & & & & & -0.25 & -0.03 & -0.01 & -0.08 & -0.21 & -0.15 & $0.31 *$ \\
\hline $\mathrm{S}$ & & & & & & & $0.32 *$ & -0.11 & $-0.30 *$ & $-0.38 *$ & -0.13 & 0.03 \\
\hline $\mathrm{B}$ & & & & & & & & -0.22 & -0.13 & $-0.70^{*}$ & 0.21 & -0.04 \\
\hline $\mathrm{Cu}$ & & & & & & & & & -0.16 & -0.11 & -0.18 & $0.31 *$ \\
\hline $\mathrm{Fe}$ & & & & & & & & & & -0.02 & -0.02 & -0.06 \\
\hline $\mathrm{Mn}$ & & & & & & & & & & & -0.21 & $-0.41 *$ \\
\hline $\mathrm{Zn}$ & & & & & & & & & & & & -0.31 \\
\hline \multicolumn{13}{|c|}{ Flower } \\
\hline Y & $0.37 *$ & $-0.40 *$ & $0.32 *$ & $-0.33 *$ & $-0.54 *$ & -0.09 & $-0.43^{*}$ & 0.06 & 0.12 & $0.36^{*}$ & -0.06 & -0.02 \\
\hline $\mathrm{N}$ & & -0.15 & $0.44^{*}$ & -0.20 & -0.22 & 0.02 & -0.08 & -0.19 & -0.23 & 0.10 & 0.00 & $0.48^{*}$ \\
\hline $\mathrm{P}$ & & & 0.25 & 0.23 & $0.53^{*}$ & 0.29 & $0.68 *$ & -0.22 & $-0.36^{*}$ & $-0.69 *$ & $0.52 *$ & $0.33 *$ \\
\hline $\mathrm{K}$ & & & & 0.10 & 0.13 & $0.38 *$ & 0.25 & -0.29 & $-0.36^{*}$ & $-0.33^{*}$ & 0.27 & $0.49 *$ \\
\hline $\mathrm{Ca}$ & & & & & $0.66^{*}$ & $0.40^{*}$ & $0.33^{*}$ & -0.27 & $-0.45^{*}$ & $-0.34^{*}$ & -0.04 & 0.06 \\
\hline $\mathrm{Mg}$ & & & & & & 0.21 & $0.47 *$ & $-0.37 *$ & $-0.41 *$ & $-0.51 *$ & 0.05 & $0.33^{*}$ \\
\hline $\mathrm{S}$ & & & & & & & $0.33 *$ & -0.13 & $-0.47^{*}$ & $-0.34^{*}$ & 0.08 & 0.17 \\
\hline B & & & & & & & & -0.13 & -0.34 & $-0.78^{*}$ & $0.47 *$ & $0.32 *$ \\
\hline $\mathrm{Cu}$ & & & & & & & & & 0.20 & -0.02 & -0.24 & -0.11 \\
\hline $\mathrm{Fe}$ & & & & & & & & & & 0.03 & -0.14 & $-0.46^{*}$ \\
\hline $\mathrm{Mn}$ & & & & & & & & & & & $-0.46^{*}$ & $-0.32 *$ \\
\hline $\mathrm{Zn}$ & & & & & & & & & & & & -0.03 \\
\hline
\end{tabular}

*significant at $\mathrm{p}<0.05$ by the significance test. The other correlations were not significant. 
Among the organs under study, the sufficiency ranges (Table 2) showed differences in some nutrients. For $\mathrm{P}$ and $\mathrm{K}$, the range was higher for the flower; however, for $\mathrm{N}, \mathrm{Cu}, \mathrm{Fe}$, and $\mathrm{Mn}$, the range was smaller. For the other nutrients, the ranges in both organs were practically the same. It was also observed that the intervals of sufficiency ranges were shorter in the flower. Comparing the ranges obtained in flower and leaf with those found in the literature for leaf (RAIJ et al., 1997; RIBEIRO et al., 1999; NATALE et al., 2002; PAULETTI; MOTTA, 2017) no similar intervals were observed, the majority being higher or lower than values found in the literature.
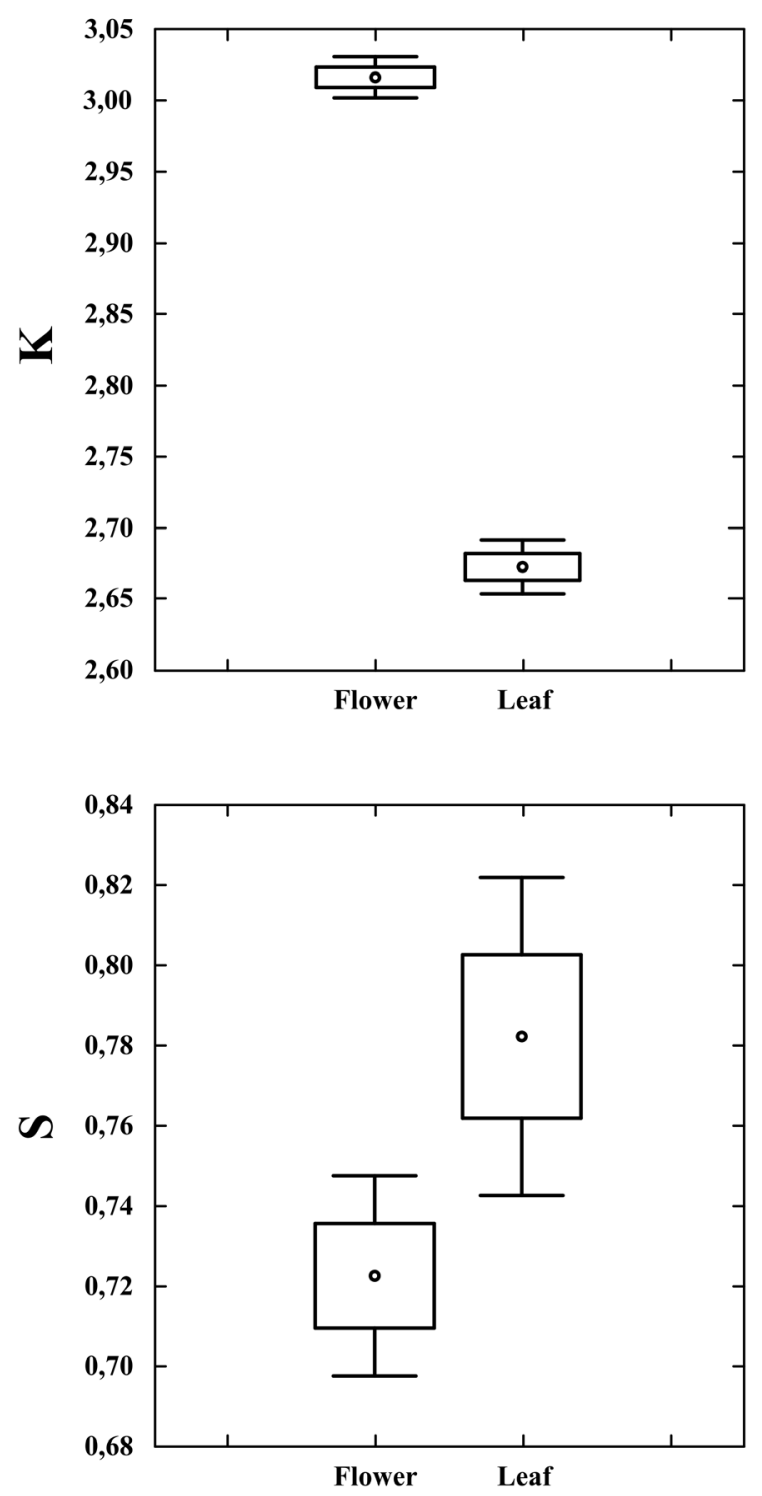

The discriminant analysis allowed observing, among all variables, which demonstrated greater importance for the evaluated organs, which simplified analysis and interpretation. The Wilks Lambda test used indicated $\mathrm{WL}=0.0538062, \mathrm{~F}=160.2207$ and $\mathrm{p}=$ 0.0000 , rejecting the $\mathrm{H}_{0}$ hypothesis and admitting that there was a difference between leaf and flower multinutrient variables. Of the thirteen variables analyzed, $\mathrm{K}$, $\mathrm{N}, \mathrm{S}, \mathrm{Ca}, \mathrm{Fe}, \mathrm{B}, \mathrm{Cu}, \mathrm{P}$, and $\mathrm{Zn}$ showed importance, in that order. However, K, N, S, and B (Figure 1) showed more important significance compared to the others (Figure 1), with $\mathrm{p}<0.01$.
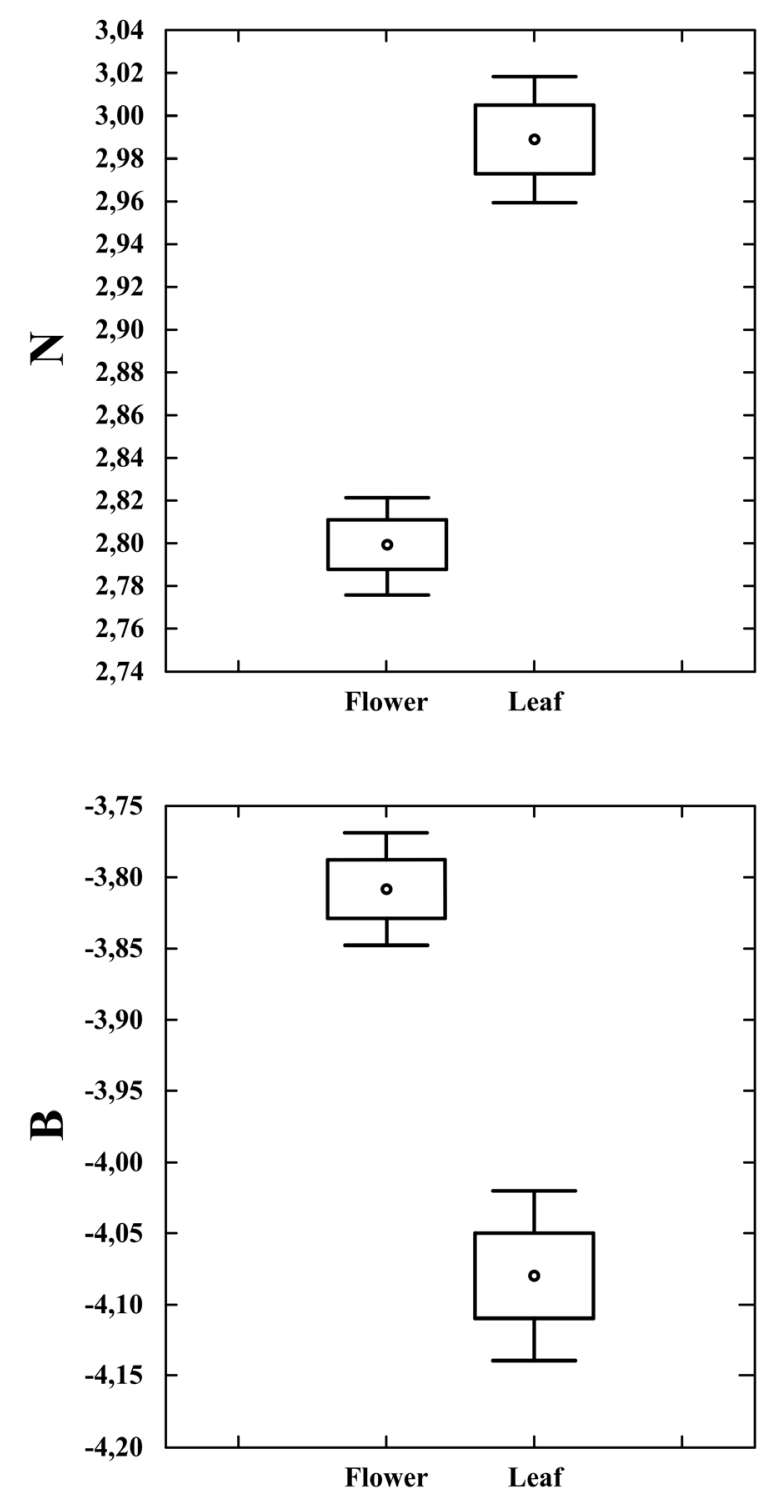

Figure 1. Box plots of multi-nutrient variables: potassium - K, nitrogen - N, sulfur - S and boron - B, considered the most important by the model, in that order. 
It is believed that $\mathrm{K}$ and $\mathrm{N}$ showed greater importance because the database comes from an experiment that verified the effect of $\mathrm{N}$ and $\mathrm{K}$ doses and the interaction of these nutrients in 'Paluma' guava trees (AMORIM et al., 2015a; AMORIM et al., 2015b). K and $\mathrm{B}$ showed higher relationships in the flower; however, $\mathrm{N}$ and $\mathrm{S}$ showed higher relationships in the leaf.

Proteins are the compounds in which most $\mathrm{N}$ and $\mathrm{S}$ are incorporated. On average, there are $34 \mathrm{~N}$ atoms for each $\mathrm{S}$ atom, with $\mathrm{N}$ content fifteen times higher in proteins; therefore, there is stoichiometry between elements (MALAVOLTA et al., 1997). B acts mainly in the flowering and growth of the pollen tube (DECHEN; NACHTIGALL, 2006), and the longest period of absorption of this nutrient is between the formation of the floral bud and full flowering (SFREDO et al., 1984; GUTERRES et al., 1988).

It was observed that, like Martinez et al. (2003), Khelil et al. (2010) and Gui et al. (2014), flower analysis proved to be an alternative tool for diagnosing the nutritional status of guava trees, but it cannot be inferred that it can replace leaf analysis. Martinez et al. (2003) reported that both diagnostic processes are complementary and that in cases of severe deficiencies or excesses, flower analysis allows corrections at the beginning of the growth and production cycle, minimizing yield and quality losses.

\section{Conclusion}

In general, flower analysis shows greater sensitivity (significant correlations) in expressing interactions between nutrients and yield, in addition to lower variability (coefficient of variation) in the nutritional contents for this organ concerning the leaf. Thus, it could be concluded that the flower may be an organ used in addition to leaf to assess the nutritional status of guava trees.

\section{References}

ALEXANDRE, J.R.; OLIVEIRA, M.L.F.; SANTOS, T.C.; CANTON, G.C.; CONCEIÇÃO, J.M.; EUTRÓPIO, F.J.; CRUZ, Z.M.A.; DOBBSS, L.B.; RAMOS, A.C. Zinco e ferro: de micronutrientes a contaminantes do solo. Natureza Online, Santa Teresa, v.10, n.1, p.23-28, 2012.

ALVARES, C.A.; STAPE, J.L.; SENTELHAS, P.C.; GONÇALVES, J.L.M.; SPAROVEK, G. Köppen's climate classification map for Brazil. Meteorologische Zeitschrift, Stuttgart, v.22, n.6, p.711-728, 2013.
AMORIM, D.A.; ROZANE, D.E.; SOUZA, H.A.; MODESTO, V.C; NATALE, W. Adubação nitrogenada e potássica em goiabeiras 'Paluma': I. Efeito na produtividade e na qualidade dos frutos para industrialização. Revista Brasileira de Fruticultura, Jaboticabal, v.37, n.1, p.201209, 2015 a.

AMORIM, D.A.; SOUZA, H.A.; ROZANE, D.E.; MONTES, R.M.; NATALE, W. Adubação nitrogenada e potássica em goiabeiras 'Paluma': II. Efeito no estado nutricional das plantas. Revista Brasileira de Fruticultura, Jaboticabal, v.37, n.1, p.210-219, 2015 b.

BATAGLIA, O.C.; FURLANI, A.M.C.; TEIXEIRA, J.P.F.; FURLANI, P.R.; GALLO, J.R. Métodos de análise química de plantas. Campinas: IAC, 1983.48 p. (Boletim Técnico, 78)

BEVERLY, R.B. Modified DRIS method for simplified nutrient diagnosis of 'Valencia' oranges. Journal of Plant Nutrition, Londres, v.10, n.9-16, p.1401-1408, 1987.

CAMACHO, M.A.; SILVEIRA, M.V.; CAMARGO, R.A.; NATALE, W. Faixas normais de nutrients pelos métodos ChM, DRIS e CND e nível crítico pelo método de distribuição normal reduzida para lanjeira-pêra. Revista Brasileira de Ciência do Solo, Viçosa, MG, v.46, p.193200, 2012.

DECHEN, A.R.; NACHTIGALL, G.R. Micronutrientes. In: FERNANDES, S.F. Nutrição mineral de plantas. Viçosa: Sociedade Brasileira de Ciência do Solo, 2006. p.328-352.

FAO - Food and Agriculture Organization of the United Nations. Faostat. Roma, 2019. Disponível em: http:// www.fao.org/faostat/en/\#data/QC/visualize. Acesso em: 10 jun. 2019.

GUI, H.P.; TAN, Q.L.; HU, C.X.; ZHANG, Y.; ZHENG, C.S.; SUN, Z.C.; ZHAO, X.H. Floral analysis for Satsuma mandarin (Citrus unshiu Marc.) nutriente diagnosis based on the relationship between flowers and leaves. Scentia Horticulturae, Amsterdam, v.169, p.51-56, 2014.(1)

GUTERRES, J.F.; BAMI, n.A.; COMIN, C.M.V. Nutrição e adubação. In: Girassol: indicações para o cultivo no Rio Grande do Sul. Porto Alegre: UFRGS, 1988. $66 \mathrm{p}$.

IBGE - Instituto Brasileiro de Geografia e Estatística. Estatísticas. Censo agropecuário. Rio de Janeiro, 2019. Disponível em: https://www.ibge.gov.br/estatisticasnovoportal/economicas/agricultura-e-pecuaria/218142017-censo-agropecuario.html. Acesso em: 10 jun. 2019. 
KHELIL, M.B.; SANAA, M.; MSALLEM, M.; LARBI, A. Floral analysis as a new approach to evaluate the nutritional status of olives trees. Journal of Plant Nutrition, Londres, v.33, n.5, p.627-639, 2010.

LANA, R.M.Q.; OLIVEIRA, S.A.; LANA, A.M.Q.; FARIA, M.V. Levantamento do estado nutricional de plantas de Coffea arabica L.pelo DRIS, na região do Alto Paranaíba - Minas Gerais. Revista Brasileira de Ciência do Solo, Viçosa, MG, v.34, n.4, p.1147-1156, 2010.

MALAVOLTA, E. Manual de nutrição mineral de plantas. São Paulo: Agronômica Ceres, 2006. 638 p.

MALAVOLTA, E.; VITTI, G.C.; OLIVEIRA, S.A. Avaliação do estado nutricional das plantas: princípios e aplicações. 2.ed. Piracibaca: POTAFOS, 1997. 319 p.

MARSCHNER, $\mathrm{H}$. Mineral nutrition of higher plants. $3^{\text {rd }}$ ed. London: Elsevier, 2012. 643p.

MARTINEZ, H.E.P.; SOUZA, R.B.; BAYONA, J.A.; VENEGAS, V.H.A.; SANZ, M. Coffee-tree floral analysis as a mean of nutritional diagnosis. Journal of Plant Nutrition, Londres, v.26, n.77, p.1467-1482, 2003.

MONTAÑÉS MILLÁN, L.; VAL, J.; BETRÁN, J.; MONGE, E.; MORENO, M.A.; MONTAÑÉS, L. Floral analysis: fresh and dry weight of flowers from diferent fruit tree species. Acta Horticulturae, Leuven, v.448, n.35, p.23-239, 1997.

NATALE, W.; COUTINHO, E.L.M.; BOARETTO, A.; PEREIRA, F.M. Goiabeira: calagem e adubação. Jaboticabal: FUNEP, 1996. 22p.

NATALE, W.; COUTINHO, E.L.M.; PEREIRA, F.M.; BOARETTO, A. Nutrients foliar content for high productivity cultivars of guava in Brazil. Acta Horticulturae, Leuven, v.524, p.383-386, 2002.

NATALE, W.; PRADO, R.M.; QUAGGIO, J.A.; MATTOS JÚNIOR, D. Guava. In: JOHNSTON, A.E.; CRISÓSTOMO, L.A.; NAUMOV, A. (Ed.). Fertilizing for high yield and quality tropical fruits of Brazil. Bern: International Potash Institute, 2007. p.103-122.

NATALE, W.; ROZANE, D.E. Análise de solo, folhas e adubação de frutíferas. Registro: Unesp, 2018. 124 p.

PARENT, L.E.; DAFIR, M. A theorical concept of compositional nutrient diagnosis. Journal of the American Society for Horticultural Science, Alexandria, v.117, n.2, p.239-242, 1992.
PAULETTI, V.; MOTTA, A.C.V. Manual de adubação e calagem para o estado do Paraná. Curitiba: SBCS/ NEPAR, 2017. 482 p.

PESTANA, M.; CORREIA.p.J; VERENNES, A.; ABADIA, J.; FARIA, E.A. The use of floral analysis to diagnose the nutritional status of oranges trees. Journal of Plant Nutrition, Londres, v.24, n.12, p.1913-1923, 2001.

POLITI, L.S.; FLORES, R.A.; SILVA, J.A.S.; WADT, P.G.S.; PINTO, P.A.C.; PRADO, R.M. Estado nutricional de mangueiras determinado pelos métodos DRIS e CND. Revista Brasileira de Engenharia Agrícola e Ambiental, Campina Grande, v.17, n.1, p.11-18, 2013.

RAIJ, B.V.; CANTARELlA, H.; QUAGGIO, J.A.; FURLANI, A.M.C. Recomendações de adubações e calagem para o Estado de São Paulo. Campinas: IAC, 1997.285p. (Boletim Técnico, 100)

RAZETO, B.; SALGADO, J. The inflorescence and fruit peduncle as indicators of nitrogen status of the avocado tree. HortScience, Alexandria, v.39, n.6, p.1173-1174, 2004.

RIBEIRO, A.C.; GUIMARÃES, P.T.G.; VENEGAS, V.H.A. Recomendação para o uso de corretivos e fertilizantes em Minas Gerais ( $5^{\text {a }}$ aproximação). 5.ed. Viçosa: SBCS, 1999. 359p.

ROZANE, D.E.; ROMUALDO, L.M.; CENTURION J.F.; BARBOSA, J.C. Dimensionamento do número de amostras para avaliação da fertilidade do solo. Semina: Ciências Agrárias, Londrina, v.32, n.1, p.111-118, 2011.

SALAZAR, D.M.; MELGAREJO, P.; MARTÍNEZ, R.; MARTÍNEZ, R.R.; HERNÁNDEZ, F.; BURGUERA, M. Phenological stages of the guava tree (Psidium guajava L.). Scientia Horticulturae, Amsterdam, v.108, p.157161, 2006.

SANZ, M.; MACHÍN, J. Aplicacíon del anális floral al prognóstico y diagnóstico del bitter-pit. Información Técnica Económica Agraria, Zaragoza, v.95, n.2, p.118124, 1999.

SANZ, M.; MONTAÑÉS MÍLLAN, L. Flowers analysis as a new approach to diagnosing the nutritional status of peach tree. Journal of Plant Nutrition, Londres, v.18, n. 8, p.1667-1675, 1995.

SANZ, M.; MONTAÑÉS MÍLLAN, L.; CARRERA, 
M. The possibility of using floral analysis to diagnose the nutritional status of pear trees. Acta Horticulturae, Leuven, v.367, n.41, p.290-295, 1994.

SANZ, M.; PÉREZ, J.; PASCUAL, J.; MACHÍN, J. Prognosis of iron chlorosis in apple trees by floral analysis. Journal of Plant Nutrition, Londres, v.21, n.8, p.16971703, 1998.

SFREDO, G.J.; CAMPOS, R.J.; SARRUGE, J.R. Girassol: nutrição mineral e adubação. Londrina: Embrapa Soja, 1984. (Circular técnica, 8).

SERRA, A.P.; MARCHETTI, M.E.; TADEU, A.C.; NOVELINO, J.O.; CAMACHO, M.A. Desenvolvimento de normas DRIS e CND e avaliação do estado nutricional da cultura do algodoeiro. Revista Brasileira de Ciência do Solo, Viçosa, MG, v.34, n.1, p.97-104, 2010.
SOUZA, H.A.; ROZANE, D.E.; AMORIM, D.A.; DIAS, M.J.T.; MODESTO, V.C.; NATALE, E. Assessment of nutritional status of guava seedlings using preliminary DRIS norms and sufficiency ranges. Journal of Plant Nutrition, Londres, v.38, p.1611-1618, 2015.

TONIN, T.A.; MUNIZ, A.S.; SCAPIM, C.A.; SILVA, M.A.G.; ALBRECHT, L.P.; CONRADO, T.V Avaliação do estado nutricional das cultivares de uva Itália e rubi no município de Marialva, estado do Paraná. Acta Scientiarum, Maringá, v.31, n.1, p.63-69, 2009.

YRUELA, I. Copper in plants. Brazilian Journal Plant Physiology, Campos dos Goytacazes, v.17, n.1.p.145-156, 2005. 